$\left.\begin{array}{c}\text { praktyka } \\ \text { snsoljaro⿰彳 }\end{array}\right\}$
Praktyka Teoretyczna

Numer 4(18)/2015

ISSN 2081-8130

DOI: $10.14746 /$ prt.2015.4.6

www.praktykateoretyczna.pl

\title{
OCCUPY: NOWA PEDAGOGIKA PRZESTRZENI I CZASU?
}

\author{
SARAH AMSLER I MIKE NEARY
}

PRZEKXAD: JAKUB KRZESKI I KRYSTIAN SZADKOWSKI

\begin{abstract}
Abstrakt: Artykuł jest pierwszą częścia projektu badawczego mającego na celu przybliżenie teoretycznego i praktycznego potencjału Occupy w oparciu o analizę ostatniej fali okupacji, która pojawiła się w odpowiedzi na politykę zaciskania pasa i prekarności na całym świecie. Podejmujemy się tego zadania jako edukatorzy, usiłujący „okupować” przestrzenie edukacji wyższej wewnątrz i na zewnątrz instytucji, w których pracujemy. Occupy wskazuje na kluczowe znaczenie czasu i przestrzeni jako pojęć, za pomoca których możliwa jest rekonfiguracja działalności rewolucyjnej. Podejmując problem (Occupy) na tym fundamentalnym poziomie przestrzeni i czasu przy pomocy krytycznego zastosowania koncepcji „,nowej pedagogiki przestrzeni i czasu" Henriego Lefebvre’a, mamy nadzieję stworzyć przestrzenie dla dalszych rewolucyjnych transformacji, rozciagając krytykę polityki przestrzeni i czasu na samą edukację i jej instytucje. Według Lefebvre’a „pedagogika przestrzeni i czasu” jest podstawą dla nowej formy „przeciw-przestrzeni”. Stwierdza on, że „wypaczone i odwrócone przestrzenie, choć poczattkowo podporządkowane, dają wyraziste dowody na prawdziwie produktywny potencjał" (2008, 383), a tym samym ukazują miejsca pęknięć w życiu codziennym i sposoby, na które może ono zostać odzyskane jako żywiołowa przestrzeń pełna radości i nadziei. W La production de l'espace to przestrzeń czasu wolnego jest tą przestrzenią, w której zajść może namysł nad oporem i jego zapoczątkowanie. Z kolei my zastępujemy tę przestrzeń ideą Occupy. Rozważamy, jak okupacja uniwersyteckich programów kształcenia, rozumiana jako produkcja krytycznej wiedzy, może również stwarzać „nową pedagogikę przestrzeni i czasu”. Okupację szkolnictwa wyższego opiszemy w odniesieniu do dwóch projektów, w które jesteśmy zaangażowani - „Student jako wytwórca” i Social Science Center.
\end{abstract}

Słowa kluczowe: Occupy, krytyczna pedagogika, student jako wytwórca, Lefebvre 
Tworzenie (czy produkcja) na skalę całej planety przestrzeni jako społecznego fundamentu pod przemienione życie codzienne otwarte na wielość możliwości - oto brzask, który zaczyna jaśnieć na horyzoncie (Lefebvre 2008, 422).

Największym dobrem jest czaso-przestrzeń: to ona zapewnia przetrwanie bytu, energię, którą ten byt zawiera i którą dysponuje (Lefebvre 2008, 350).

Odmieńmy życie! Odmieńmy społeczeństwo! Te hasła nie znaczą nic bez produkcji adekwatnej przestrzeni (Lefebvre 2008, 59).

Nie da się eksmitować idei, której czas właśnie nadszedł (Occupy Wall Street 2011).

\section{Praktyka i teoria}

Każde $z$ nas jest już od dawna zaangażowane w rozwijanie pedagogiki przestrzeni i czasu. Praktycznie, a więc od strony, która podkreśla instytucjonalne i systematyczne transformacje, praca ta polegała na zaprojektowaniu w 2006 roku sali zajęciowej wraz ze studentami i współpracownikami z Uniwersytetu w Warwick związanymi z Reinvention Centre for Undergraduate Research (Neary i Thody 2009). Sala ta została stworzona, aby zachęcać do nawiązywania bliskich interakcji intelektualnych między kadrą a studentami, podważających dominujące stosunki władzy, które cechują uniwersytecką przestrzeń nauczania (Lambert 2011). Praca ta przekształciła się w znacznie większy projekt badawczy, skupiający się na akademickim zaangażowaniu w kreowanie przestrzeni wykładowej i zajęciowej na dwunastu uniwersytetach w Wielkiej Brytanii (Neary i Saunders 2011; Neary i in., 2010). Jej celem nie było po prostu uzyskanie odpowiedzi na pytanie, jak wspierać „studenckie zaangażowanie” albo jak zagwarantować „zadowolenie studentów”, ale raczej pobudzanie debaty na temat znaczenia i celu edukacji wyższej czy też ,idei uniwersytetu” jako projektu „kolektywnego pracownika umysłowego" (Wacquant 2007, 57).

Z innej perspektywy, kładacej nacisk na opór wobec utowarowienia pracy intelektualnej i społecznej przez prefigurację ich alternatyw w życiu codziennym, praca ta wiązała się z rozwojem krytycznej pedagogiki w istniejących przestrzeniach i sytuacjach edukacyjnych, budowaniem kulturowego oporu przeciw logice kapitału w instytucjach akademickich (Amsler 2011a, 2011b) i kooperacyjnym tworzeniem nowych przestrzeni autonomicznych dla produkcji wiedzy w „pozaedukacyjnym” kontekście walk społecznych i przestrzeni publicznej (Amsler $\mathrm{i}$ in. 2010).

Ostatnio w projekty te włączono nowe zadania, z którymi związana jest nasza dwójka: „Student jako wytwórca” oraz Social Science Centre, pierwsze na Uniwersytecie w Lincoln, drugie - obejmujące całe to miasto. 
Z perspektywy teoretycznej ta nowa pedagogika oparta jest na rozumieniu przestrzeni i czasu jako czaso-przestrzeni [space-time], w której ludzkie życie pojmowane jest na sposób kosmologiczny, jako część „bardzo rozwiniętego całokształtu” (Marks 1986, 55), w ramach Marksowskiej teorii wartości. W tym układzie to nie tyle abstrakcyjne przestrzenie sa produkowane przez stosunki społeczne kapitalistycznej produkcji (Lefebvre 2008), ale raczej substancja świata społecznego jest czaso-przestrzeń, wytwarzana w szczególnych formach społecznej praktyki: przez nadawanie formy towarowej, w której wartość użytkowa/konkretna przemienia się w wartość wymienna/abstrakcyjną w procesie zdominowanym przez „przemoc abstrakcji” (Lefebvre 2008), jak i przez opór wobec tej praktyki. Innymi słowy, towar jest szczególną formą czaso-przestrzeni, zawierająca w sobie jej własną wybuchową sprzeczność (Postone 1993).

Naszym celem jest odzyskanie („detonacja”), „okupacja” tych momentów czasoprzestrzeni za pomoca „,nowej pedagogiki czasu i przestrzeni”, która może zostać określona jako produkcja wiedzy krytycznej w życiu codziennym. Podstawą owej wiedzy jest refleksyjność praktyczno-krytyczna. Ta refleksyjność jest zgodna z naszym sformułowaniem czasoprzestrzeni, a więc teoria i praktyka są względem siebie immanentne (Gunn 1989). Jej nieodłącznym aspektem jest podważanie prawomocności swoich własnych pojęć przez rozpoznanie siebie jako tkwiącej w świecie społecznych praktyk, wyłaniającym się z i nierozłącznym od społeczeństwa, które sama próbuje zrozumieć. Proces ten jest ekspansywny, tworzy nową wiedzę i znaczenia, unika kolistości i nieskończonego regresu: „dobrych rozmów” (Gunn 1989).

W sensie praktycznym oznacza to, że „edukacja” nie może być oddzielona od „życia” wewnątrz instytucji, a myślenie o edukacji nie może odseparować się od przestrzeni i czasu, w których produkujemy wiedzę - i które, w tym ujęciu, są potencjalnie wszędzie i zawsze. Zostało to również opisane jako „,bezwaględna krytyka wszystkiego, co istnieje; bezwzględna w tym sensie, że krytyka nie boi się ani własnych wyników, ani konfliktu z istniejącymi potęgami” (Marks 1976, 417). Jednak działalność żyjących życiem Occupy na całym świecie i nasze własne doświadczenia każą uznać, że krytyczno-praktyczna refleksyjność jest czymś więcej niż zwykła intelektualną czy teoretyczną produkcją wiedzy; że jest ucieleśniona, afektywna, intersubiektywna i kolektywna; a produkcja nowych radykalnych podmiotowości i rewolucyjnych stosunków jest kluczowa dla oporu przeciw zdominowanemu czasowi i przestrzeni w szerszym ujęciu. 


\section{Sytuując Occupy}

Trudno jednoznacznie określić, gdzie i kiedy zaczął się ruch Occupy, zwłaszcza teraz, gdy rozpoczęły się kłączowate okupacje wszystkiego i wszędzie - przestrzeni publicznych i prywatnych, szkół, banków, bibliotek, budynków rządowych, edukacji, polityki czy patriarchatu (Colvin i Philips 2011; Lunghi i Wheeler 2012). W rzeczy samej ta nowa i zdeterytorializowana wszechobecność \#Occupy wzbudziła ekscytację. Dlaczego? Użytek z okupacji jako taktyki walki politycznej - czy tego, co Tim Gee nazwał bardziej szczegółowo „taktyką tworzenia przestrzeni autonomicznych jako form oporu” - nie jest nowy: miał swój początek w rewolucyjnej, anarchistycznej i feministycznej polityce lat sześćdziesiactych i siedemdziesiatych dwudziestego wieku. Nawet „,narodziny” ruchu OWS (Occupy Wall Street) w Zuccotti Park były tylko jednym z wydarzeń całej serii okupacji (Brown 2012; Federici 2011; Gee 2012; Graeber 2011). Tuż przed tym, w 2007 i 2008 roku, studenci kilku krajów europejskich zorganizowali strajki okupacyjne i wykłady otwarte [teach-outs], by protestować przeciw prywatyzacji szkolnictwa wyższego, a w 2009 roku studenci z Wielkiej Brytanii okupowali ponad trzydzieści uniwersytetów, dając wyraz sprzeciwu wobec decyzji instytucji, która odmówiła zerwania stosunków z Izraelem po ataku na strefę Gazy. W tym samym roku, podczas rzadziej wspominanych walk o spowolnienie procesu redukcji miejsc pracy w przemyśle, pracownicy brytyjscy okupowali fabrykę turbin wiatrowych Vestas na wyspie Wight, a w roku 2011 - Prisme w Dundee. Nowe fale okupacji na kampusach i w zakładach pracy oraz nowe grupy zaangażowanych intelektualistów, takie jak Edu-Factory czy Occupy Everything, przetoczyły się przez Europę niedługo później. Państwa na całym świecie odpowiedziały jeszcze większą liczbą antydemokratycznych mechanizmów zapobiegających, represjonujących i rozpędzających okupacje (Calhoun 2011; Brown 2012).

Naukowe zainteresowanie okupacją jako istotnym fenomenem teoretycznym i politycznym zaczęło się nasilać w 2010 roku, zaraz po początkowych działaniach międzynarodowego ruchu studentów, akcjach UK Uncut oraz obywatelskich okupacjach w Stanach Zjednoczonych (Hancox 2011; Solomon i Palmieri 2011) i umocniło się wskutek wiralowej mobilizacji rewolucyjnej w trakcie Arabskiej Wiosny (Butler 2011; Federici 2011; Graeber 2011; Žižek 2012; Possible Futures 2012) ${ }^{1}$. Od tego czasu ruch ten był z jednej strony chwalony jako wskrzeszenie radykalnej wyobraźni, demokracji bezpośredniej i powszechnej woli politycznej, z drugiej dostrzegano w nim pozbawioną kierunku chwilową modę, oderwaną od przeżywanych doświadczeń, pragnień i interesów szerszej publiki.

1 Szeroki wybór materiałów poświęconych Occupy można znaleźć w Berkeley Journal of Sociology (http://berkeleyjournal.org/), jak również na stronie projektu „Possible Futures” prowadzonego przez U.S. Social Science Reasearch Council (http://www.possible-futures.org/category/occupy-movement/). 
Abstrahując od tej spolaryzowanej debaty, odnotować należy, że istnieją istotniejsze kwestie: w jakim stopniu krytyczne, demokratyczne, horyzontalne i prefiguratywne wymiary Occupy - szczególnie te zmaterializowane w okupywaniu przestrzeni i czasu - tworza materialne i kulturowe podstawy pod szersze przemiany społecznej? Czy podstawowe założenia i różnorodne praktyki Occupy, a także ich słabości i sprzeczności sugerują nową „pedagogikę przestrzeni i czasu” (Lefebvre 2008, 354), która może przenikać nasilające się walki przeciwko wszelkim formom dehumanizacji we współczesnym społeczeństwie, włączając w to jako jedne z wielu te, które mają swoje źródło w przemocy kapitalistycznej abstrakcji? Czy dają nadzieje wszystkim tym ludziom, którzy nie mogą fizycznie okupować, odzyskiwać przestrzeni lub czasu? I wreszcie, pytanie najistotniejsze dla naszego tekstu, czy Occupy otwiera nowe możliwości odzyskania edukacji wyższej poza logiką kapitalistyczna, możliwości tworzenia nowych form nauczania, uczenia się i krytycznego wglądu, które pozwalają na produkcję autonomicznych podmiotowości i emancypacyjnych stosunków wewnątrz, ale - co istotniejsze - poza formalnie „okupowanymi” przestrzeniami i środowiskami?

\section{Occupy i edukacja}

Ruch Occupy jest na wiele sposobów jednoznacznie pedagogiczny. W jego formalnej konstytucji istnieją silne elementy edukacji, bowiem niektóre z jego korzeni sięgają utrwalonych krytyk kapitalistycznych instytucji wiedzy i edukacji. Studenci i naukowcy okupuja teraz budynki edukacyjne w celu spowolnienia procesu całkowitego ich wchłonięcia przez logikę komercyjnego kapitalizmu - czy też, jak dziś w Arizonie, logikę rasistowskiej hegemonii. W północnoamerykańskim ruchu istnieje wiele grup roboczych skupiajacych się przede wszystkim na kwestiach edukacyjnych (takich jak Empowerment and Education - centrum Occupy University, Student Debt i Forum on the Commons). W Londynie Tent City University był integralną i powszechnie znaną częścią obozowiska na placu św. Pawła, popularyzująca ideę, zgodnie z która „,każdy może nauczać i każdy może się uczyć”, przekraczająca podziały na formalną i nieformalną edukacje, „tradycyjnych” i „organicznych” intelektualistów. Poza tymi najbardziej widocznymi przedsięwzięciami aktywistycznymi na całym świecie dochodzi do znacznie większej liczby prób okupowania szkół i koledży, gdzie nauczyciele, studenci i uczniowie wykazują się odwagą, solidarnością i nadzieją, które dają im siłę na stawianie oporu korporacyjnej i menadżerskiej dominacji w ich własnych instytucjach. Tym samym, choć nie jest jasne, czy Occupy jest momentem przełomowym w politycznych i ekonomicznych walkach przeciwko kapitalistycznej hegemonii, ruch ten z cała pewnością edukuje.

Poza tymi oczywistymi manifestacjami radykalnej polityki pedagogicznej Occupy wpisuje się również w dłuższą i zróżnicowaną historię, którą Mark Coté i inni nazwali 
„edukacyjnym wymiarem walk wewnątrz i przeciwko neoliberalizmowi” (2007, 3). Jako że pierwszorzędną funkcją tak edukacji formalnej, jak i nieformalnej jest produkcja posłusznych, neoliberalnych podmiotów, konsumentów-obywateli, walki o autonomię zawsze obejmowały wysiłki powołania ,instytucji wiedzy, tworzenia, opieki, wynalazczości i edukacji niezależnych od kapitału” (Bifo 2007, 10). Ułatwiło to wyłonienie się „poszerzonego pojęcia walki, które podkreśla wagę codziennych praktyk i sporów o znaczenie reprodukcji oraz transformacji hegemonicznych stosunków władzy" (Coté i in. 2007, 5; Federici 2011). Radykalna polityka wiedzy była tym samym kluczowa zarówno dla prac rewolucyjnych feministek czy ruchów antykolonialnych, oddolnych organizacji robotniczych czy anarchistycznych w ostatnim wieku, jak i dla „nowych” ruchów społecznych tego stulecia - w celu jej realizacji ruchy te często tworzyły autonomiczne instytucje edukacyjne (Day 2005; Federici 2011; Graeber 2011c). Logika i język Occupy rezonują z tymi projektami, które są eksperymentalne, ciagle rozrastające się, skupione raczej na drodze niż na samym celu, usytuowane poza hegemonicznymi dyskursami i praktykami, pełne radykalnej nadziei (Coté i in. 2007, 14).

Odchodząc nawet dalej od tych jednoznacznie edukacyjnych kwestii, owe rozrastające się praktyki okupacyjne sa pedagogiczne w tym sensie, w jakim Jacques Rancière przypisuje prawdziwie krytycznej pedagogice zadanie „przekształcania wspólnego doświadczenia tego, co postrzegalne” $i$,tworzenia nowego krajobrazu tego, co widzialne, możliwe do wyartykułowania i zrobienia" $(2010,140,148)$. Okupacje rozbijaja dominujące polityczne podmiotowości właśnie dlatego, że wytwarzanie nowych stosunków społecznych wiąże się z wytwarzaniem procesów alternatywnego upodmiotowienia. Jak argumentuje Silvia Federci, ,ruch Occupy [...] rozwija alternatywę dla polityki reprezentacji i staje się w efekcie szkołą bezpośredniej demokracji i samorządności” $(2011,2)$.

Czy jednak ruch Occupy - lub też wydarzenie Occupy, jak chcą nazywać je niektórzy - jest szkołą? Jeśli tak, to jakim typem szkoły? Czy trzeba partycypować w okupacji, żeby nauczać albo uczyć się w jej ramach? Czego o formach wiedzy i praktykach produkcji wiedzy, które służą życiu demokratycznemu, uczą nas te doświadczenia? W listopadzie zeszłego roku dysydenci-rezydenci Zuccotti Park w oświadczeniu publicznym wydanym zaraz po eksmisji stwierdzili, że „ten rozrastający się ruch jest czymś więcej niż protestem, więcej niż okupacją czy pewną formą taktyki”, właśnie dlatego, że liczba jego członków daleko wykraczała poza tych zebranych „na miejscu” (Occupy Wall Street 2011). Orzekli również, że ruch ten jest po pierwsze $i d e q$ czy skolektywizowanym poczuciem sprawczości, a zatem nie może on być nigdy „eksmitowany” ze stosunków społecznych.

O ile ta oda do radykalnej mocy zawartej w idei Occupy jest całkowicie adekwatna, to pytanie o jej społeczny oddźwięk i trwałość mogą być już bardziej skomplikowane, niż sugerowałyby to optymistyczne konstatacje. Chcielibyśmy rozwinąć ten argument w dwóch kierunkach. Pierwszy z nich wiąże się z rozpoznaniem, że ruch Occupy nie może być właściwie 
zrozumiany, jeśli będziemy o nim myśleć jedynie jako o idei, a co za tym idzie, jego ewikcja nie zniszczenie - i permanentny kryzys trwać będą tak długo, aż nie zrozumiemy go w bardziej holistyczny, materialistyczny sposób. Drugi kierunek dotyczy próby wyobrażenia sobie tego, jak rewolucyjna energia ruchu może zostać rozszerzona poza najbardziej widoczne okupowane przestrzenie - na instytucje i codzienne praktyki w kapitalizmie. Choć wezwanie do „okupacji wszystkiego" słyszalne jest coraz głośniej, to poza obozowiskami wydaje się, że łatwiej niż kiedykolwiek porzucamy wiarę w przyszłość uniwersytetu. Naszym zdaniem pojęcie „zawłaszczenia”, w znaczeniu w jakim posługuje się nim Lefebvre, może wnieść do tego projektu więcej niż pojęcie okupacji².

\section{Okupacja programów kształcenia?}

W tej części interesuje nas możliwość okupacji programów kształcenia czy zawłaszczania społecznej przestrzeni i czasu edukacji w taki sposób, który pozwoli nam określić czego, jak i dlaczego ludzie się uczą. Po co jednak okupować programy kształcenia? Wewnątrz obowiązujących ram słowo to nie przywodzi na myśl o wiele więcej niż represyjne kanony, standaryzację, analizę porównawcza, kontrolę jakości i egzaminy. W rzeczy samej, tak długo, jak nasze rozumienie relacji pomiędzy wiedza a władza pozostaje zredukowane - w ramach zinstytucjonalizowanych programów kształcenia - do „potwierdzenia niedefiniowalnej i nieuchwytnej wielości rzeczy, gubiącej się w klasyfikacjach, opisach i segmentacjach”, tak długo programy kształcenia mogą być postrzegane jako przemocowe abstrakcje same w sobie (Lefebvre 2008, 81). Zamiast okupować programy kształcenia, może powinniśmy znieść je albo porzucić - „odszkolnić” społeczeństwo (Illich 1971)?

Właśnie zniesienie „programów”, czasem na rzecz pustej i wydawałoby się transparentnej siatki wolnych czasów i przestrzeni, gotowych do bycia zapełnionymi przez każdego, kto chciałby czegoś uczyć, postrzegane jest jako demokratyczna pedagogika par excellence $\mathrm{w}$ wielu współczesnych radykalnych projektach edukacyjnych.

Być może jednak, zgodnie z rozpoznaniami Lefebvre'a, wiara w taką możliwość „odszkolnienia” społeczeństwa jest iluzoryczna. W życiu społecznym nie może być „pustych” przestrzeni, ideologicznie niezajętych form, które czekają na wypełnienie ich radykalną treścią. „Zawsze jesteśmy w procesie okupacji”, twierdzi Really Open University, „,czasu, przestrzeni, naszych wartości, etyki i poglądów. Wszystko wokół nas jest zatem cały czas zajęte”. Praktyka okupacji jest procesem uczenia się, „jak rozumieć to, co »okupuje« daną przestrzeń”,

2 „O przestrzeni naturalnej, która została zmodyfikowana, by służyć potrzebom danej grupy, można powiedzieć, że została przez nią zawłaszczona. Mienie jako własność jest w najlepszym wypadku koniecznym warunkiem, najczęściej zaś jedynie epifenomenem 'zawłaszczającej' działalności, której najwyższą formą ekspresji jest sztuka” (Lefebvre 2008, 165). 
a następnie jak odzyskać te narzędzia do realizacji alternatywnych czy nawet niemożliwych celów - rozpoznając cały czas, że okupujemy skomplikowaną rzeczywistość zakorzenionych przestrzeni i czasów, i że efekty ich przecinających się trajektorii leżą często poza naszym zasięgiem zrozumienia (Really Open University 2010). Życie społeczne może być postrzegane jako nieuniknione tak długo, jak produkcja wiedzy jest kanalizowana, parametryzowana, dyscyplinowana i kontrolowana. Poza jawnymi i ukrytymi programami kształcenia, które determinuja to, czego ludzie uczą się w szkole i na uniwersytecie, i co często jest u swojej podstawy upolitycznione, istnieja „formy, procesy i miejsca edukacji dziejące się poza sformalizowanym nauczaniem", za sprawa publicznych pedagogik oraz silnie edukacyjnych elementów szerszych walk społecznych i politycznych, z których wszystkie przyczyniają się do tworzenia politycznych podmiotowości (Sandlin i in. 2011).

Choć możemy uciec od konkretnego pojęcia programu kształcenia lub z niego zrezygnować, nie możemy uniknąć konieczności produkowania relacji społecznych, przez które wytwarzana jest wiedza, to jest programu kształcenia. Jak przekonuje Lefebvre, „,stosunki społeczne, które są konkretnymi relacjami, nie istnieją inaczej niż w przestrzeni i przez nią" (2009, 404). Program kształcenia nie może być zatem rozumiany jedynie jako abstrakcyjny zestaw idei, korpusów wiedzy czy metod pedagogicznych. Może istnieć tylko wtedy, gdy zostanie powołany w ramach szczególnych stosunków społecznych i materialnych środowisk, przestrzeni i czasów. „Program kształcenia” jest nazwą praktyk, które mediuja politykę wiedzy i edukacji, ekonomię polityczna przestrzeni i czasu oraz możliwość autonomii. Pytanie nie brzmi zatem, czy powinniśmy dysponować teoriami i praktykami programu kształcenia, ale raczej: jak ustanowić kolektywną kontrolę determinowania tego, „dla kogo, wskutek czyjej sprawczości, dlaczego i jak” wiedza jest produkowana (Lefebvre 2009, 116).

Co więc może znaczyć „okupowanie” programu kształcenia?

Najbardziej dosłowne metody opierają się na uczeniu ludzi o ruchu Occupy w oficjalnych edukacyjnych programach kształcenia (Reynolds 2012), czy też na wprowadzaniu „okupacji” do klasy i organizacji młodzieżowych za pomocą kontaktów zewnętrznych (Richardson 2012). Inne podejście, zapożyczone od amerykańskich organizacji Educators' Network for Social Justice and Rethinking Schools, polega na aranżowaniu symultanicznych, ale zdecentralizowanych działań pedagogicznych: żeby „uczyć czegoś, czego chciałeś uczyć, ale tego nie robiłeś, bo nie pasowało [do ustandaryzowanych programów kształcenia] bla, bla. To twoja klasa; okupuj ja za pomocą ważnych i kreatywnych lekcji!” (ENSJ 2011). Duch okupacji przywoływany jest tutaj w zdeterytorializowany sposób: „Nie musimy zabierać namiotów i śpiworów na place naszych miast, by partycypować w ruchu Occupy - przekonuja - możemy również okupować nasze sale wykładowe, okupować program kształcenia, a następnie zbierać historię tego, co zrobiliśmy" (Bieglow 2011). Takie praktyki rezonują z innymi formami akademickiego aktywizmu w tych przestrzeniach, w których „kapitalizm kognitywny nie uległ 
całkowitemu domknięciu” i gdzie możliwe jest „utrzymanie radykalnego programu kształcenia obok praktyk głównonurtowych, a nawet powstanie przeciwstawnych inicjatyw" (DyerWitheford 2007, 59).

Być może wytwarza to subwersje czy „pęknięcia” wewnątrz kapitalizmu; dla pewności, nawet sam akt odrzucenia dominacji i działania autonomicznego może mieć polityczną moc transformacji (Holloway 2009). Choć takie akty ucieleśniaja radykalnego ducha Occupy, jednocześnie prowadzą do mylenia ciagłych, kolektywnych praktyk okupacji ze zindywidualizowanymi, symbolicznymi i anachronicznymi aktami, które moga tymczasowo zakłócić status quo, ale cofają się przed naruszeniem ekonomii politycznej przestrzeni, czasu i podmiotowości. Jak radziła Judith Butler, podczas gdy manifestacje niezadowolenia moga dać emancypacyjnego kopa, ,istotne jest, żeby móc usytuować gniew i destytucję w kontekście ruchu społecznego" (Bella 2011).

Równie ważna jest możliwość odniesienia gniewu i wyobraźni do przeżywanych doświadczeń oraz materialnych warunków naszego codziennego życia. Tak jak w przypadku wszystkich zdeterytorializowanych systemów władzy nie możemy tu po prostu odmówić obstawania przy programie kształcenia. Jakie strategie intelektualne i polityczne są właściwe dla skonceptualizowania okupacji programu kształcenia? Jakie sa przestrzenie i czasy programu kształcenia, które możemy inaczej zamieszkać? Wreszcie, z jakimi zewnętrznymi makroi mikropolitykami projekt ten musi być powiązany, żeby mógł posiadać potencjał przekształcania wykraczający poza indywidualną percepcję?

\section{Program kształcenia jako pedagogika przestrzeni i czasu}

W przeciwieństwie do wykładowców studiów etnicznych w szkołach w Arizonie, których podręczniki do historii oddolnej zostały ostatnio zakazane, akademicy w Wielkiej Brytanii nie stracili jeszcze całkowicie czy dosłownie kontroli nad tym, czego uczą. Straciliśmy raczej kontrolę nad forma, strukturą i funkcją wiedzy akademickiej; określaniem czasu i przestrzeni, w których (się) uczymy; relacjami między filozofią edukacji a materialnym środowiskiem nauki; stosunkami pomiędzy studentami i nauczycielami. Literatura krytyczna poświęcona kapitalizmowi akademickiemu pełna jest krytyk neoliberalnych pedagogik przestrzeni i czasu w uczeniu (się): „krępowania”, „ścieśniania” i „kurczenia” się przestrzeni intelektualnej i czasu, „przepełniania” i „wyludniania” przestrzeni fizycznej, „kolonizacji” i „przechwytywania” przestrzeni politycznej; „usuwania” i „grodzenia” przestrzeni społecznej, „przejmowania” przyszłej przestrzeni i - mniej metaforycznie - alienacji oraz wycieńczenia, które biorą się z intensyfikacji, wyzysku i uabstrakcyjnienia pracy akademickiej.

Hegemoniczne panowanie nad warunkami i stosunkami produkcji programów kształcenia, a w szczególności dyscyplinowanie wiedzy przez jej kanalizowanie za pomocą 
abstrakcyjnych i policzalnych form, jest kluczowe dla globalnego projektu przekształcenia instytucji edukacyjnych w maszyny biznesowe (w celu uzupełnienia kontekstu historycznego zob. Hall 2007, 113). Przestrzenna i temporalna organizacja uczenia (się) na uniwersytetach jest tym, co sprawia, że produkcja kapitalistycznej wiedzy jest możliwa, jako że przestrzeń uniwersytecka jest „mobilizowana w celach produkcyjnych przez komodyfikację, pracę abstrakcji, przekształcanie w wartość wymienną, fetyszyzację i modulowanie" (Lefebvre 2008, $338)$.

Edukacyjne programy kształcenia są więc zdominowane i dominują nad przestrzenią, a zatem, podobnie jak współczesne okupacje, są „miejscami, w których możliwa jest konstrukcja koncepcji niekapitalistycznego społeczeństwa” (Federici 2011, 3). Podważyć stosunki wytwarzania edukacyjnych przestrzeni i czasu przezprodukowanie ich inaczej jest zatem aktem najwyższej wagi politycznej - takim, który wymaga materialnego i mentalnego odzyskania, a w końcu akcji politycznej. Prawdopodobne jest zatem, że każda obiecująca próba okupacji programu kształcenia, która odzyskuje go, by uwspólnić, zdefetyszyzować i zdekomodyfikować edukacje, stwarzałaby bezpośrednie zagrożenie dla logiki kapitału i dawałaby impuls do walki politycznej.

Nie jest jednak jasne, czy w dłuższej perspektywie praca ta jest możliwa do wykonania za pomoca praktyk okupacyjnych, które zrobiły już wiele na rzecz pobudzenia radykalnej wyobraźni, demokratyzacji uczenia (się) w przestrzeni publicznej, proliferacji produkcji nowych krytycznych teorii politycznych i praktyk, popularyzowania alternatywnych modeli demokracji radykalnej i tchnięcia nowego życia zarówno w politykę, jak i edukację. Do jakiego stopnia okupowane przestrzenie sa tymi, do których odwołuje się Federici, rozrywajacymi czas i przestrzeń czy zawłaszrzajacymi je? Zdaniem Lefebvre’a „odzyskanie nie może być mylone z inną praktyka, która choć jest z nią blisko związana, musi być rozpatrywana jako osobna, czyli z détournement' (2008, 167). Odzyskanie nie jest po prostu aktem zabrania przestrzeni, ale na bardziej fundamentalnym poziomie jest w rzeczywistości innym zdominowaniem przestrzeni: czyni ja „naturalna przestrzenia, zmodyfikowana, by służyć potrzebom i celom danej grupy” (2008, 166). Nie powinno się jednak zakładać, że istnieje tu jakaś hierarchia potencjalności. Zdaniem Lefebvre'a:

détournement $\mathrm{i}$ odzyskanie przestrzeni mają wielkie znaczenie, gdyż uczą nas wiele na temat produkcji nowych przestrzeni. W przypadku okresów tak trudnych, jak ten obecny, dla (kapitalistycznego) sposobu produkcji, któremu grozi wyginięcie, a który mimo to jednocześnie usiłuje złapać nowe tchnienie (za pomoca produkcji środków produkcji) takie taktyki détournement moga mieć nawet większe znaczenie niż twórcze wysiłki (produkcja). Abstrahując, jednym z efektów takich taktyk jest zajmowanie przez grupy przestrzeni, których wcześniejsza forma, stworzona do innych celów, jest nieadekwatna do potrzeb ich przyszłego życia wspólnotowego (Lefebvre 2008, 168). 
W rzeczy samej, częścią siły taktyk dywersyjnych Occupy jest właśnie to: ich zdolność do unaocznienie stopnia, w jakim niegdyś wspólne czy grodzone przestrzenie publiczne są nieadekwatne do potrzeb egalitarnego, sprawiedliwego i demokratycznego społeczeństwa. Ale czy możliwa jest również intensyfikacja odzyskującego potencjału tych okupacji wskutek spojrzenia na nie przez pryzmat kosmologicznej wersji przestrzeni-czasu/czaso-przestrzeni?

\section{To jest Kosmos: czasoprzestrzeń i przemoc abstrakcji}

Lefebvre mówi jasno: „Największym dobrem jest czaso-przestrzeń: to ona zapewnia przetrwanie bytu, energię, którą zawiera byt i którą dysponuje” (Lefebvre 2008, 350). Dla Lefebvre’a istotę czaso-przestrzeni opisuje Marksowska teoria wartości opartej na pracy, w której wartość użytkowa przemienia się w wartość wymienną w procesie zdominowanym zarówno przez przemoc abstrakcji, jak $i$ opór wobec niej, który Lefebvre określa „pprzeciwprojektami”.

Lefebvre odnajduje radykalną podmiotowość na jednym z dwóch biegunów formy towarowej, jako wartość użytkową: „wartość użytkowa konstytuuje jedyne prawdziwe bogactwo, co pomaga przywrócić jej istotność, teraz zniekształconą" (2008, 341). Wartość użytkowa jest dla niego „społecznie rzeczywistą” (342), „naturalną, materialną i bezpośrednią” substancja życia (344), której „materialne cechy znajduja się w zawieszeniu wraz z potrzebami, do których się odnoszą" (343-344). Aby polityka zawłaszczenia przezwyciężyła politykę dominacji, Lefebvre twierdzi, że konieczny jest „prymat użyteczności nad wymienialnością” (410).

Merrifield powtarza to sformułowanie, nawołując do stworzenia świata, w którym „wartość użytkowa góruje nad wartością wymienną" (2011,161). Podstawą dla tej alternatywnej koncepcji wartości nie jest społeczna teoria krytyczna czy krytyczna ekonomia polityczna, ale raczej zasady moralne: „etyka społeczna” - a nie „etyka biznesu” (161) - ugruntowana w tym, co Merrifield nazywa Innym pracy abstrakcyjnej, „naturą i możliwościami konkretnych ludzi” (21).

Merrifield sugestywnie przedstawia, jak ta radykalna forma bytu mogłaby wyglądać.

To, co jest stawka, jest zarazem temporalne, dotyczy nie linearnego czasu, ale rytmicznego aspektu organizacji, falującego rozproszenia aktywistycznej wrażliwości, czyli walki, powszechnej insurekcji; nie ma to raczej nic wspólnego z ludźmi łączącymi się przestrzennie, ale z czasem, który poświęcają na nawiązywanie więzi ludzkich, na odczuwanie fal rezonujących na całym świecie i wokół nich insurekcji (Merrifield 2011, 76). 
Siłą tego sformułowania jest oferowana przez nie rama, wewnątrz której można konceptualizować opór wobec kapitalistycznych stosunków społecznych. Ograniczenie stanowi jednak przywiązanie do podejścia, które usiłuje krytykować - niezależnie od tego, jak radykalne są te fale, ich moc wyczerpuje się z każdym uderzeniem, powielając i powtarzając walki w coraz bardziej fragmentarycznych formach i nie podejmując jednocześnie najważniejszego zadania.

Przez osadzenie radykalnej podmiotowości w wartości użytkowej Lefebvre i jego kontynuatorzy powielają zatem teoretyczne ujęcia, które Marks usiłuje dekonstruować i wobec których sam Lefebvre wypowiadał się krytycznie: „niezdefiniowana i nieokreślona wielość rzeczy gubi się w klasyfikacjach, opisach i podziałach” (2008, 81). Oto, co Marks określa fetyszyzmem. Wartość użytkowa nie znajduje się naturalnie poza stosunkami społecznymi produkcji kapitalistycznej, ale sama w sobie jest społeczną formą urzeczowionych stosunków społecznych. Wartość użytkowa jest także charakterystyką „,wartości w ruchu” jako wartość wymienna: jako materialność niematerialności. Próba przypisania antykapitalistycznych tendencji wartości użytkowej, podjęta przez Lefebvre’a i innych krytycznych teoretyków społecznych, za pomocą naturalizacji jej ontologicznych możliwości, często wiązana z wrodzona kreatywnością i pozytywnym postrzeganiem ludzkości, polega na przypisaniu jej formy bytu, której zdaniem Marksa nie może posiadać: „Hipostazowanie konkretu i rozpoznanie kapitału za pomocą manifestacji abstrakcji rodzi formę »antykapitalizmu«, która usiłuje obalić istniejący porządek społeczny z pozycji właściwie immanentnej dla tego porządku" (Postone 2000, 18).

Marksowska krytyczna teoria społeczna nie implikuje wyższości wartości użytkowej nad tą wymienną, ale detonacje , wartości w ruchu”: stosunku kapitalistycznego jako takiego (Holloway i in. 2009). Detonacja ta jest wpisana w formę towarowa - włączając w to utowarowioną wiedzę - a także w wybuchową sprzeczność pomiędzy wartością użytkową a wartością wymienna/abstrakcyjną, w proces utowarowienia zdominowany przez przemoc abstrakcji. Ta „przemoc abstrakcji” nie wytwarza tylko wartości dodatkowej, substancji rozszerzającej uniwersum społeczne, ale również opór, walkę klas: (nie)możliwość życia jako żywej śmierci, tworzenia innego wymiaru czaso-przestrzeni, to jest przyszłości; czy też mocy ludzkiego życia, okiełznanej dla dobra ludzkości tak, by czas nie był już po prostu miara pracy, ale rytmem, który odpowiada „,tętnu czy pulsacjom ludzkiego życia” (Neary i Rikowski 2000). Żywej pracy. Możemy opisać ten opór w naszym zrekonstruowanym „uniwersum społecznym” jako anty-wartość w ruchu (Dinerstein i Neary 2002).

Tym samym udaje się wytworzyć radykalna podmiotowość nie jako byt osadzony w wartości użytkowej, ale w produkcji nowych form wiedzy krytycznej w życiu codziennym, czy też w praktycznej refleksyjności. Krytyczna wiedza praktyczna formowana jest z tej samej materii społecznej co „anty-wartość w ruchu”: tak jak czas tkwi w przestrzeni, a wartość 
użytkowa tkwi w wartości wymiennej, podobnie teoria tkwi w praktyce jako krytycznej refleksyjności czy żywej wiedzy, obejmującej samo życie.

W następnej części opisujemy dwie próby „okupacji programu kształcenia”, to jest tworzenia praktycznej refleksyjności za pomocą nowej pedagogiki przestrzeni i czasu. Pierwsza ma miejsce w ramach Uniwersytetu w Lincoln, druga zaś odbywa się w całym tym mieście.

\section{Jak to się robi w praktyce}

\section{Student jako wytwórca}

„Student jako wytwórca” to zasada organizująca kształcenie i uczenie się na Uniwersytecie w Lincoln, w Wielkiej Brytanii. Projekt ten trwa już od 2007 roku, a w latach 2010-2013 zosta1 wsparty grantem z Higher Education Academy. „Student jako wytwórca” nie wyrasta z ruchu Occupy, ale współdzieli z nim wiele cech i ambicji. Podobnie jak Occupy, „Student jako wytwórca" w świadomy sposób odnosi się do swojej radykalnej historii, w tym przypadku koncepcji uniwersytetu jako postępowego przedsięwzięcia politycznego (Lyotard 1997) oraz swoich korzeni w polityce rewolucyjnej lat sześćdziesiątych dwudziestego wieku. Projekt jest wpisany w krytyczną teorię społeczną, która zainspirowała wydarzenia Maja 1968 roku: prace Waltera Benjamina, Guy Deborda, Henriego Lefebvre'a i innych. Hasło tytułowe projektu, „Student jako wytwórca” zaczerpnięte zostało natomiast z wykładu Twórca jako wytwórca wygłoszonego przez Waltera Benjamina przed komitetem antyfaszystowskim w Paryżu w 1933 roku, odpowiadającego na pytanie o to, w jaki sposób radykalni intelektualiści działają w momentach kryzysu (Benjamin 2011). Podobnie jak Occupy, nasz projekt powiązany jest z innymi rewolucyjnymi przedsięwzięciami edukacyjnymi, np. Edu-factory, Knowledge Liberation Front (KLF) czy sam ruch Occupy (np. Tent City University) oraz z ostatnimi protestami studenckimi w Europie i na świecie (Neary 2012). „Student jako wytwórca” również jest zakorzeniony w jednoznacznie krytycznej pedagogice, przeciwstawionej konsumerystycznej ideologii neoliberalizmu, a więc ujmuje studenta jako wytwórcę, a nie konsumenta. Także nasz projekt znajduje się w szerszej idealistycznej ramie: odzyskać „ideę Uniwersytetu" nie w ramach filozoficznej debaty, ale jako kierunek działania, jako program nauczania „wewnątrz” współczesnego uniwersytetu i „przeciwko” (Holloway 2010) niemu. Podobnie jak Occupy, „Student jako wytwórca” jest anty-programem nauczania (University of Utopia 2009), którego istoty nie stanowi po prostu kształcenie i uczenie się, ale produkcja wiedzy, będącej rewolucyjnym projektem politycznym: „teoretyczną i praktyczną wiedzą odnoszącą się do życia społecznego w ramach danej wspólnoty" (Lefebvre 1969, 155) czy też „̇̇ywą wiedzą” (Roggero 2011). 
Chociaż czerpią z dwudziestowiecznego awangardowego marksizmu, nie wszyscy nauczyciele akademiccy na Uniwersytecie w Lincoln są rewolucyjnymi marksistami. „Student jako wytwórca" tworzy ramę dla debat i dyskusji dotyczących polityki, strategii kształcenia i uczenia się na uniwersytecie w oparciu o zradykalizowany polityczny dialekt. Biorąc pod uwagę to, w jakim zakresie język menadżeryzmu zdominował dyskurs dotyczący szkolnictwa wyższego, jest to nieliche osiagniecie.

„Student jako wytwórca” działa w różnych wymiarach.

Pierwszym z nich jest paradygmat rozwoju programów nauczania obejmujących wszystkie przedmioty i programy na wszystkich poziomach uniwersytetu. W momencie (ponownego) zatwierdzania programu zachęca się i wymaga od naukowców takiego zaplanowania kursów, by wykorzystywały one „techniki” (Benjamin 2011) „Studenta jako wytwórcy". To intelektualne wyzwanie pobudza naukowców do obrony ich aktualnych praktyk w zakresie kształcenia w kontekście debaty o „Studencie jako wytwórcy”. Nalega się, by poznali badania pedagogiczne wskazujące na skuteczność uczenia się przez odkrywanie i działanie (Healey i Jenkins 2009; Brew 2006) oraz by zajęli stanowisko w sporze o to, czy nowoczesny uniwersytet jest fundamentalnie dysfunkcyjny, gdyż dwie aktywności stojące u jego rdzenia badanie i kształcenie - działają przeciwko sobie (Boyer 1998).

„Techniki” „Studenta jako wytwórcy”, co do których nalega się, by naukowcy wpisali je w swoje programy nauczania, obejmują badania studenckie oraz działania zbliżone do badań na wszystkich poziomach studiów licencjackich i magisterskich, służące produkcji nowej wiedzy, a nie zwykłe urządzenia pedagogicznego. Obstaje się również przy tym, by naukowcy pozostawili w projekcie i procesie realizacji programów studiów miejsce na głos studencki, co ma na celu demokratyzowanie sposobów poznania. Podobny nacisk kładzie się na to, w jakich ramach dany program studiów jest skontekstualizowany, w jakiego rodzaju przestrzennych krajobrazach kształcenia jest osadzony: na geograficznym poziomie sali zajęciowej, kampusu i jego zewnętrza; ale również na poziomie przestrzeni horyzontalnej, gdzie współpraca może się zwielokrotniać. Podkreśla się również wagę uświadamiania studentom, znajdującym się w otoczeniu kształcenia naszpikowanym cyfrowymi technologiami edukacyjnymi, polityki produkcji maszynowej. Wreszcie zaś zwraca się uwagę na to, w jaki sposób programy studiów nakierowane są na przyszłość - dotyczącą zarówno momentu obecności studentów na uniwersytecie, jak i czasu, gdy opuszczą już oni jego mury - dając im poczucie, że są częścią tworząca tę przyszłość - bardziej jako podmioty/sprawcy niż przedmioty/ofiary historii.

Tego rodzaju podejście wsparte jest szkoleniem w zakresie kształcenia, jak również (nie)formalną siecią pomocy dla nauczycieli na poziomie instytucjonalnym oraz w całym Lincolnshire, we współpracy z Bishop Grosseteste University College Lincoln. Poza tą regionalną koncentracją „Student jako wytwórca” współpracuje również na poziomie krajowym $\mathrm{z}$ innymi uniwersytetami: Uniwersytetem $\mathrm{w}$ Warwick $\mathrm{w}$ zakresie programu 
finansowego, Uniwersytetem Central Lancashire w zakresie promowania Brytyjskiej Konferencji Badań Studenckich oraz z Uniwersytetem w Plymouth w zakresie rówieśniczego wspierania kształcenia studenckiego [peer-assisted student learning]. „Student jako wytwórca” nawiązuje również kolejne stosunki z Christ Church Canterbury, Uniwersytetem w Hertfordshire oraz Uniwersytetem Zachodniej Szkocji; natomiast na poziomie międzynarodowym z Uniwersytetem w Galway z Irlandii, z Uniwersytetem w Maastricht w Holandii oraz z Uniwersytetem Macquarie w Australii.

Jednakże, na jeszcze bardziej fundamentalnym poziomie, „Student jako wytwórca” jest odpowiedzią na obecny kryzys szkolnictwa wyższego, który jest częścią szerszego kryzysu społeczno-politycznego, mającego źródło w polityce zaciskania pasa oraz prekarności (Roggero 2011). Podobnie jak Occupy, „Studenta jako wytwórcę” można umieścić w ramach radykalnych reakcji na kryzys szkolnictwa wyższego zarówno w kategoriach czasowych, jak i przestrzennych.

Ten właśnie „kryzys Uniwersytetu” opisuje Andy Merrifield w swoich pracach poświęconych Lefebvre’owi:

\begin{abstract}
abstrakcyjna przestrzeń zaczyna pokrywać cały świat, przekształcając wysiłki badaczy $\mathrm{i}$ intelektualistów w pracę abstrakcyjną oraz zmieniając pracę uniwersytecką w kolejna abstrakcyjną przestrzeń. Niespodziewanie swoboda wyrazu oraz umysłowa praca konkretna - tworzenie oraz upowszechnianie krytycznych idei - w coraz większym stopniu doznaje ataku ze strony tego samego utowarowienia, które Lefebvre usiłowal zdemistyfikować. Nagle przestrzeń intelektualna - akademicka czy ideowa przestrzeń w uniwersytetach czy na kartach ksiazzek - stała się w pewien sposób kolejną neokolonią kapitalizmu, a badacze - jednocześnie sprawcami i ofiarami, kolonizatorami i skolonizowanymi, strażnikami i więźniami (Merrifield 2011, 119).
\end{abstract}

Używając terminologii temporalnej, Merrifield (2011) dokonuje powiązania tego procesu z rewolucyjna nauką mechaniki kwantowej oraz z The Coming Insurrection, żądając: „polityki czasu, jak również polityki przestrzeni, dwóch odnóg radykalnego ataku, w ramach którego aktywiści stają się tajemnymi podwójnymi agentami, wędrowcami przemierzającymi czas, jak i gwiezdnymi kadetami, podróżnikami oraz bohaterami nowej marksistowskiej kwantowej grawitacji”. Cytując zaś The Coming Insurrection, stwierdza: „nie oznacza to dla nas posiadania terytorium. Raczej jest to kwestia zwiększania zwartości komun, cyrkulacji oraz solidarności, aż do momentu, w którym terytorium staje się nieczytelne, nieprzejrzyste dla wszelkiej władzy. Nie chcemy okupować terytorium, chcemy być terytorium" (The Invisible Committee 2010, 108).

Pytanie brzmi zatem, jak być oporem: rewolucyjna kosmologia („zwrot”) czasoprzestrzeni staje się kwestią egzystencjalną (Taylor 2011). Co stanowi istotę tego egzystencjalnego zwrotu? (Taylor 2010). 
Jego sednem jest krytycznie refleksyjna wiedza w określonym kontekście: przestrzeń i czas Occupy. „Student jako wytwórca” dąży do tego, by stać się tego rodzaju formą krytycznie refleksyjnej wiedzy w kontekście szkolnictwa wyższego. Jest „zbiorowym pracownikiem intelektualnym" (Wacquant 2007, 57), projektem radykalizującym Bourdieu, w którym centralna kwestia „idei uniwersytetu”, znaczenie i cel edukacji wyższej, wynajdywana jest na nowo na poziomie rozwoju programów kształcenia w ramach demokratycznego, horyzontalnego procesu pedagogicznego. W tym znaczeniu można powiedzieć, że „Student jako wytwórca” okupuje program nauczania, tworząc formę tego, co Richard Gunn określił mianem refleksyjnej praktyki/praktycznej wiedzy.

„Student jako wytwórca” zajmuje pozycje „,wewnątrz i przeciwko” idei uniwersytetu jako instytucji neoliberalnej, jednakże w ramach tego kontekstu student zdecydowanie pozostaje „studentem” (Neary i Hagyard 2011). Ograniczeniem „Studenta jako Wytwórcy” jest to, że student nie przekracza swojej własnej instytucjonalnej i wyidealizowanej formy: ,idei studenta” (Neary 2010). By student stał się czymś więcej, niż jest, neoliberalny uniwersytet musi zostać poddany rozkładowi i ponownie ustanowiony jako inna forma „społecznego poznania” (Neary 2011).

\section{Social Science Centre}

Grupa naukowców i studentów, działająca poza murami uniwersytetu w mieście Lincoln, dąży do stworzenia nowej formy społecznego poznania. Ta nowa forma uzyskała nazwę Social Science Centre (SSC). Chociaż wielu spośród zaangażowanych w przedsięwzięcie naukowców i studentów pracuje na Uniwersytecie w Lincoln, nie ma ono bezpośredniej relacji z Uniwersytetem, ani z żadnymi innymi uniwersytetami.

Stanowi raczej rozwijającą się edukacyjną kooperatywę, której uczestnicy dążą do stworzenia możliwości prowadzenia studiów zaawansowanych i badań w ramach nauk społecznych, mających szansę być zarówno wolnymi od opłat, jak również intelektualnie i politycznie demokratycznymi. SSC stara się zorganizować swój program nauczania tak, by odpowiadał „wartościom akademickim, w tym krytycznemu myśleniu, eksperymentowaniu, współdzieleniu, ocenie przez równych, kooperacji, współpracy, otwartości, debacie i konstruktywnemu sporowi” bardziej niż „krótkoterminowości, wysokiej konkurencyjności czy nastawieniu na zysk sektora prywatnego [i w coraz większym stopniu również publicznego]"3. Podobnie jak inne alternatywne projekty edukacyjne w Wielkiej Brytanii SSC zostało powołane do życia przez akademików, studentki i politycznych aktywistów na początku 2011 roku w ramach sprzeciwu zarówno wobec ograniczania finansowania uniwersytetów, jak i ich

\footnotetext{
${ }^{3}$ Fragment pochodzi ze strony SSC (http://socialsciencecentre.org.uk/).
} 
prywatyzacji, oraz z zamiarem stworzenia przestrzeni dla edukacji wyższej w zakresie nauk społecznych, która byłaby autonomiczna wobec instytucjonalnej podległości (Eve i Jones 2011; Fuller 2011).

Natomiast inaczej niż niektóre projekty, z którymi SCC łączą pewne podobieństwa, nie znajduje się ono w warunkach „okupacji” żadnej z tych instytucji. W rzeczywistości oprócz świetlic, w których planowane są spotkania, nie posiada żadnego stałego przestrzennie miejsca i być może nigdy takiego nie uzyska. Działa raczej poprzez tworzenie „kontr-przestrzeni” edukacyjnych, w których produkcja emancypującej wiedzy dokonuje się wskutek ponownego przywłaszczenia oraz, tam gdzie to niezbędne, możliwej produkcji społecznych przestrzeni, czasu oraz relacji uczenia się. Brown $(2011,56)$ definiuje okupację jako „zorganizowaną próbę doprowadzenia skłotingu do jego granic pod względem skali, liczby oraz prędkości w obrębie legalnych i nielegalnych działań, jak również poprzez negocjację i konfrontację". Inaczej niż w ramach okupacji przedsiębranych w charakterze taktyki politycznej obrony, w SSC praktyka edukacyjna ulega ponownemu wyobrażeniu oraz ukonstytuowaniu poprzez przestrzenie i czas życia codziennego. Jednakże Brown również argumentuje na rzecz tego, że niedawne okupacje są po prostu manifestacją szerszego projektu „odzyskiwania dóbr wspólnych - począwszy od środowiska i zasobów naturalnych, po nasze umysły, ciała i pracę, coś, co zostało nam odebrane dawno temu przez kapitalistyczną prywatyzacje”. Jako takim „celem okupacji nie sa już fizyczne przestrzenie czy obiekty, ale wszystko, wszędzie - włączając w to nas samych” (Brown 2012, 56), a zatem możliwe jest to dla każdego i wszędzie (Brown 2012, 56).

Członkowie i członkinie Social Science Centre nie starają się tworzyć nowych możliwości edukacyjnych w obliczu bezpośredniego zagrożenia ewikcją czy przemoca, ale odrzucać hegemoniczne formy instytucjonalnego uznania i tworzyć formy autonomiczne. Richard Hall (2011) nazywa to aktem „pedagogicznego oporu”. Jest to eksperyment niezupełnie (czy jeszcze nie) eksperyment „rozkładania szkolnictwa wyższego, przekształcający je w formę masowej intelektualności” w ramach społeczeństwa (Hall 2011), ale polegający na radykalnej deinstytucjonalizacji go poprzez, na przykład, odrzucanie hegemonicznych form ewaluacji i akredytacji w celu przyswojenia wartości użytkowej krytycznej wiedzy przy jednoczesnym redukowaniu jej wartości dla wymiany. Ten projekt programów studiów posiada radykalnie polityczne aspiracje, ponieważ „w tym procesie nadzieja wiąże się z tym, że studenci jako badacze stają się rewolucyjnymi istotami społecznymi w ramach otwartych, społecznie ukierunkowanych przestrzeni bardziej niż zinstytucjonalizowanymi agentami”, a to z kolei upowszechni procesy uczenia się, które „sprzęgnięte będa we wspólnotowe rozwiązywanie problemów i transformację" (Hall 2011).

Hall zauważa, że podobnie jak akty odmowy politycznej, praca w ramach Social Science Centre wymaga odwagi. Odnotowuje, że ,jest to odwaga, której wymagaja odzyskanie i reprodukcja naszej polityki i naszych stosunków społecznych w obliczu ich grodzenia" (Hall 
2011). W tym momencie większa część tej pracy wkładana jest w to, co często pojmowane jest jako przyziemne zadania formułowania kolektywnego rozumienia krytycznych pojęć, organizowania przestrzeni oraz czasu spotkania, planowania działań oraz wydarzeń jak również powolnego budowania bardziej otwartych i refleksyjnych wzajemnych relacji. Może to nie wyglądać jak miejskie powstanie, ale o to dokładnie chodzi. Podobnie jak inne formowane obecnie alternatywy dla kapitalistycznych systemów społecznych, oparte na okupowaniu przestrzeni i czasu w innych miejscach, mikropolitykach oporu oraz tworzenia, zadania te sa kluczowe dla ruchu (Feigenbaum 2012). Procesy okupowania wiedzy oraz bardziej pragmatycznego wynajdywania uniwersytetu na nowo kierują się podobną logika. Natomiast za sprawą uczenia się podobnych działań, uczenia się tego, jak być krytycznie i praktycznie refleksyjnym zarówno indywidualnie, jak i razem, otwierają się nowe możliwości przestrzeni i czasu.

\section{Zakrzywienie kształcenia: czego się uczymy?}

Wielu spośród zaangażowanych w ruch Occupy, szczególnie ci, którzy żyją i pracują w terytorialnie odwróconych przestrzeniach, często odnoszą się do swoich doświadczeń w ramach tych przestrzeni jako do „zakrzywienia kształcenia”. Nasze próby okupacji, tworzenia odchyleń w ramach oraz, tak jak to tylko możliwe, przyswajania przestrzeni i czasu naszej własnej pracy edukacyjnej współdzielą elementy przyspieszenia, rozszerzenia i intensyfikacji możliwości, wyłaniających się za sprawą odmowy bycia określanym przez istniejace formy społeczne oraz kolektywne i za sprawa autonomicznego produkowania naszych własnych relacji z przestrzenią, czasem i sobą nawzajem. Nie tylko za pomoca odmiennego porządkowania przestrzeni i czasu, ale w celu tworzenia radykalnych form czasoprzestrzeni dzięki wyzwalaniu społecznej mocy ludzkości - zamkniętej w formie towarowej jako sposobowi przyswajania przyszłości innej niż tylko kryzys i katastrofa (Neary 2004).

„Student jako wytwórca” oraz Social Science Centre sa, w pewnym sensie, wysiłkami na rzecz okupacji programów kształcenia. Oba starają się zrewolucjonizować stosunki społeczne, w ramach których wytwarza się wiedzę, odrzucić instytucjonalne nakazy jej przechwytywania jako pracy abstrakcyjnej oraz stworzyć warunki kolektywnego uczenia się, którego pożyteczność nie może zostać włączona w istniejące mechanizmy pomiaru wartości. Jednakże są to projekty, które wyraźnie się od siebie różnią. Pierwszy z nich dotyczy pracy wewnątrz i przeciwko istniejącemu systemowi uniwersyteckiemu w celu przekształcenia go. Drugi, choć w żadnym wypadku nieuciekający całkowicie od instytucji, stara się stworzyć przestrzenie, czasy i stosunki uczenia się, które są autonomiczne względem uniwersytetu neoliberalnego i zakorzenione w codziennym życiu lokalnych wspólnot, w przeciwieństwie do abstrakcji stosunków społecznych przejawiających się za pośrednictwem wymiany pieniężnej. 
Obydwa stanowią zaś trwające do dziś eksperymenty. Tym, co je łączy, jest zrozumienie, że pragnienie wynalezienia na nowo współczesnego uniwersytetu dla ludzkich celów „,nie oznacza nic, jeśli nie wytworzy się odpowiedniej przestrzeni” (Lefebvre 2008, 59), oraz że produkcja tego rodzaju przestrzeni - jak i czasów, stosunków oraz sposobów poznania - jest ostatecznie projektem politycznym.

Te eksperymenty z krytyczno-praktyczną refleksyjnością, podjęte w duchu i atmosferze ruchu Occupy, pozwalają również na krytyczny wgląd w ograniczenia i możliwości okupowania programów kształcenia. Nie wystarczy stwierdzić na przykład, że pracujemy „wewnątrz-przeciwko-poza” edukacją wyższą, uniwersytetami, państwem, systemem klas, patriarchatem czy kapitalizmem (Asher i in. 2010; Holloway 2009). W istocie przyjmowanie tej pozycji w obrębie wysoce zinstytucjonalizowanych przestrzeni może często legitymizować próżne poczucie, że możemy być jednocześnie wszędzie i nigdzie - krytyczni względem kapitalizmu, a jednocześnie reprodukujący go poprzez zachowania i własne inwestycje; krytyczni względem przechwytywania społecznej wiedzy i ludzkiej kreatywności w obrębie uniwersytetu, a jednocześnie tworzący wiedzę, która jest przechwytywana przez te formy instytucjonalnego uznania. Niemożliwe jest bycie wyłącznie wewnątrz, przeciwko, czy poza istniejącymi warunkami życia społecznego - jak wskazuje Lefebvre, ,żadna z przestrzeni nigdy nie znika całkowicie". Okupowanie programów kształcenia domaga się zatem tego, żebyśmy stali się otwarci na zmianę kierunku oraz odzyskanie nas samych. Okupacja ilustruje pewnego rodzaju kolektywną, twórczą walkę, której tego rodzaju krytyczno-praktyczna samorefleksyjność wymaga, jak również rzuca wyzwanie tym, którzy kultywują ducha Occupy w obrębie szkolnictwa wyższego, prowokując, by przyswajali oni przestrzenie, czas oraz stosunki produkcji krytycznej wiedzy w życiu codziennym.

Kryzys - szkolnictwa wyższego oraz uniwersytetu, jako część ogólnego i historycznego kryzysu kapitalizmu - odsłaniał coraz większą ilość obiecujących przestrzeni dla radykalnej krytyki tego systemu oraz przemocy abstrakcji, na której się wspiera. Occupy ożywia nadzieje pokładaną w potędze idei dzięki władzy działania oraz pokazuje, jak wygląda i jak odczuwane jest ponowne przyswajanie czasów, przestrzeni oraz wrażliwości, które niezbędne są do angażowania się w krytyczną i praktyczną refleksyjność dotyczącą warunków i przyszłości naszego wspólnego istnienia.

Kolejny krok to odbycie „dobrych rozmów” (Gunn 1989) z tymi, którzy i które przeżywają swe życia w ramach Occupy w jego różnych artykulacjach, jak również z nami samymi.

Przetożli: Jakub Krzeski i Krystian Szadkowski Redakcja przektadu: Anna Piekarska 


\section{Wykaz literatury}

Alcoff, Linda. 2011. "Occupy: Stage Two." Possible Futures: A Project of the U.S. Social Sciences Research Council. http:/ /www.possible-futures.org/2011/12/21/occupy-stage-two/

Amsler, Sarah. 2011a. "Beyond All Reason: Spaces of Hope in the Struggle for England's Universities." Representations 116: 90-114.

Amsler, Sarah. 2011b. "From »Therapeutic" to Political Education: the Centrality of Affective Sensibility in Critical Pedagogy." Critical Studies in Education 52(1): 47-64.

Amsler, Sarah, Joyce Canaan, Stephen Cowden, Sara C. Motta i Gurnam Singh [red.]. 2010. Why Critical Pedagogy and Popular Education Matter Today. Birmingham: Centre for Sociology, Anthropology and Politics.

Asher, Gordon, Leigh French, Neil Gray i John Holloway. 2010. "In-against-and-beyond labour." Variant 41. http:/ /www.variant.org.uk/41 texts/jholloway41.html.

Bella, Kyle. 2011. "Bodies in Alliance: Gender Theorist Judith Butler on the Occupy and Slut Walk Movements." Truthout 11. http://www.truth-out.org/bodies-alliance-gendertheorist-judith-butler-occupy-and-slutwalk-movements/1323880210.

Benjamin, Walter. 2011. Twórca jako wytwórca. Tłum. Robert Reszke. Warszawa: Wydawnictwo KR.

Berardi, „Bifo” Franco. 2007. „From Intellectuals to Cognitarians.” W Utopian Pedagogy: Radical Experiments against Neoliberal Globalization, [red.] Coté,, Richard Day i Greig de Peuter. Toronto: University of Toronto Press.

Bernhardt, Dan. 2012. "The Occupy Effect." The Occupied Times. http://theoccupiedtimes.org/? $\mathrm{p}=2382$.

Bigelow, Bill. 2011. “Occupy the Curriculum.” Rethinking Schools 7. http:/ / rethinkingschoolsblog.wordpress.com/2011/11/07/occupy-the-curriculum.

Bourdieu, Pierre. 2004. Science of Science and Reflexivity. Oxford: Polity.

Boyer, Ernest. 1998. The Boyer Report: Reinventing Undergraduate Education. New York: State University of New York at Stony Brook.

Brew, Angela. 2006. Research and Teaching: Beyond the Divide. London: Palgrave Macmillan.

Brown, Nathan. 2012. "Occupations: Oakland.” Radical Philosophy January-February: 53-54.

Butler, Judith. 2011. "Bodies in Alliance and the Politics of the Street." Transversal September.

Calhoun, Craig. 2011. Evicting the Public. http://www.possiblefutures.org/2011/11/19/evicting-the-public-why-has-occupying-public-spacesbrought-such-heavy-handed-repression/

Cardenas, Micha. 2011. "How Many Sexual Assaults Happened at \#OccupyLA?” Occupy Everything 15 December. http:/ / occupyeverything.org/2011/how-many-sexual-assaultshappened-at-occupyla/.

Colvin, Naomi i Bryn Phillips. 2011. "Occupy London is 50 Days Old - Now It's Time to Occupy Everywhere.” The Guardian 4 December. http://www.guardian.co.uk/ commentisfree/2011/dec/04/occupy-london-50-days-everywhere.

Coté, Mark, Richard Day i Greig de Peuter [red.]. 2007. Utopian Pedagogy: Radical Experiments against Neoliberal Globalization. Toronto: University of Toronto Press.

Couldry, Nick i Natalie Fenton. 2012. "Occupy: Rediscovering the General Will in Hard Times." Possible Futures: A Project of the U.S. Social Sciences Research Council. http://www.possible-futures.org/2011/12/22/rediscovering-the-general-will/. 
Day, Richard. 2005. Gramsci is Dead: Anarchist Currents in the New Social Movements. New York: Pluto.

Debord, Guy. 2006. Społeczeństwo spektaklu. Tłum. Mateusz Kwaterko. Warszawa: Państwowy Instytut Wydawniczy.

Deseriis, Marco i Jodi Dean. 2012. “A Movement Without Demands?” Possible Futures: A Project of the U.S. Social Sciences Research Council. http://www.possiblefutures.org/2012/01/03/a-movement-without-demands/.

Dinerstein, Ana i Michael Neary. 2002. The Labour Debate: The Theory and Practice of Capitalist Work. London: Ashgate.

Dyer-Witheford, Nick. 2007. "Teaching and Tear Gas: The University in the Era of General Intellect.” W Utopian Pedagogy: Radical Experiments Against Neoliberal Globalization. Red. Mark Coté, Richard Day i Greig de Peuter. Toronto: University of Toronto Press.

Educators' Network for Social Justice. 2011. “Occupy the Curriculum” event 5-9 December.

Eve, Martin i Jennifer Jones. "Angry Young Academics Striving for More Than Consumerism." The Guardian blogs June 2011. http://www.guardian.co.uk/highereducation-network/blog/2011/jun/15/univeristies-radical-academics-jobs-training.

Federici, Silvia i Max Haiven. 2011. "Feminism, Finance and the Future of \#Occupy: An Interview with Silvia Federici." https://zcomm.org/znetarticle/feminism-financeand-the-future-of-occupy-an-interview-with-silvia-federici-by-max-haiven/

Feigenbaum, Anna. 2012. "The Campfire Chats Project." Protest Camps. http://protestcamps.org/about/the-campfire-chats-project/.

Fuller, Steve. 2011. "Lincoln to Reconnect the University with Its Roots." Discourses of Dissent 22 February. http:/ / discoursesofdissent.com/2011/02/22/steve-fuller-lincoln-to-reconnect-the-university-with-its-roots/\#comments.

Gee, Tim. 2012. "Lines of Dissent: OccupyLSX and the Camp for Climate Action." Occupied Studies 1. http:/ /occupiedstudies.org/articles/lines-of-dissent.html.

Gillespie, Thomas i Victoria Habermehl. 2012. "On the Graduate with No Future." W Occupy Everything! Reflections on Why It's Kicking Off Everywhere. Red. Alessio Lunghi i Seth Wheeler. New York: Autonomedia.

Graeber, David. 2011a. “Occupy Wall Street’s Anarchist Roots.” Al-Jazeera 30 November. http://www.aljazeera.com/indepth/opinion/2011/11/ 2011112872835904508.html.

Graeber, David. 2011b. “Occupy Wall Street Rediscovers the Radical Imagination.” The Guardian 28 September. http://www.guardian.co.uk/commentisfree/cifamerica/ 2011/sep/25/occupy-wall-street-protest.

Graeber, David. 2011c. "Situating Occupy: Lessons From the Revolutionary Past." AdBusters 2 December. http://www.adbusters.org/magazine/99/world-revolution-2011.html.

Gunn, Richard. 1989. "Marxism and Philosophy: A Critique of Critical Realism." Capital and Class 13(1): 87-116.

Hall, Richard. 2011. "A Teach-in at Tent City and the Struggle for Alternatives." DMU Learning Exchanges 10 November. http://www.learnex.dmu.ac.uk/2011/11/10/a-teachin-at-tent-city-university-and-the-struggle-for-alternatives/.

Hall, Stuart. 2007. "Universities, Intellectuals and Multitudes: an Interview with Stuart Hall." W Utopian Pedagogy: Radical Experiments Against Neoliberal Globalization. Red. Mark Coté, Richard Day i Greig de Peuter. Toronto: University of Toronto Press.

Hancox, Dan [red.]. 2011. Fightback! A Reader on the Winter of Protest. London: Open Democracy. 
Healey, Mick i Alan Jenkins. 2009. Developing Undergraduate Research Enquiry. York: Higher Education Academy.

Holloway, John, Fernando Matamoros i Sergio Tischler. 2009. Negativity and Revolution: Adorno and Political Activism. London: Pluto.

Horton, Myles i Paulo Freire. 1990. We Make the Road by Walking: Conversations on Education and Social Change. Philadelphia: Temple University Press.

Illich, Ivan. 1971. Deschooling Society. London: Marion Boyers Publishing.

The Invisible Committee. 2009. The Coming Insurrection. Los Angeles: Semiotext(e).

Lambert, Cath. 2011. "Psycho Classrooms: Teaching as a Work of Art." Social and Cultural Geography 12(1): 27-46.

Lefebvre, Henri. 1969. The Explosion: From Nanterre to the Summit. Paris: Monthly Review Press.

Lefebvre, Henri. 2008. The Production of Space. Oxford: Wiley Blackwell.

Lunghi, Alessio i Seth Wheeler [red.]. 2012. Occupy Everything! Reflections on Why It's Kicking Off Everywhere. New York: Autonomedia.

Lyotard, Jean-François. 1997. Kondycja ponowoczesna. Raport o stanie wiedzy. Tłum. Małgorzata Kowalska i Jacek Migasiński. Warszawa: Fundacja „Aletheia”.

Marks, Karol. 1971. „Marks do Rugego, Kreuznach, we wrześniu 1843 r.”. W Karol Marks i Fryderyk Engels. Drieła T. 1. Warszawa: Książka i Wiedza.

Marks, Karol. 1986. Zarys krytyki ekonomii politycznej. Tłum. Zygmunt Jan Wyrozembski. Warszawa: Książka i Wiedza.

Merrifield, Andy. 1993. „Place and Space: a Lefebvrian Reconciliation.” Transactions of the British Institute of Geographers 18: 516-531.

Merrifield, Andy. 2011a. Magical Marxism: Subversive Politics and the Imagination. London-New York: Pluto Press.

Merrifield, Andy. 2011b. Lefebvre: A Critical Introduction. New York-London: Routledge.

Neary, Mike. 2004. “Travels in Moishe Postone's Social University: A Contribution to a Critique of Political Cosmology." Historical Materialism 12(3): 239-269.

Neary, Mike. 2010. "Student as Producer: Bringing Critical Theory to Life Through the Life of Students." Roundhouse: a Journal of Critical Social Theory: 36-45.

Neary, Mike. 2012. "Beyond Teaching in Public: The University as a Form of Social Knowing." W Towards Teaching in Public: Making the Modern University. London-New York: Continuum: 148-164.

Neary, Mike. 2013. "Teaching Politically: Pedagogy, Policy and the New European University.” Journal for Critical Education Policy Studies 10(2): 233-257.

Neary, Mike i Glenn Rikowski. 2000. "The Speed of Life: The Significance of Karl Marx's Concept of Socially Necessary Labour-Time.” Tekst przestawiony na The British Sociological Association Annual Conference Making Time-Marking Time. University of York 17-20 April.

Neary, Mike i Angela Thody. 2009. "The Learning Landscapes: Constructing a Contemporary University." W The Future of Higher Education: Policy, Pedagogy and the Student Experience. Red. Les Bell, Howard Stevenson i Mike Neary. London-New York: Continuum: 3042.

Neary, Mike i Joss Winn. 2009. "Student as Producer: Reinventing the Undergraduate Curriculum." W The Future of Higher Education: Policy, Pedagogy and the Student Experience. 
Red. Les Bell, Howard Stevenson i Mike Neary. London-New York: Continuum: 126139.

Neary, Mike, Andrew Harrison, Giles Crellin, Nayan Parekh, Gary Saunders, Fiona Duggan, Sam Williams i Simon Austin. 2010. Learning Landscapes in Higher Education: Report. Lincoln: Centre for Education Research and Development, University of Lincoln.

Neary, Mike i Andy Hagyard. 2011. "Pedagogy of Excess: an Alternative Political Economy of Student Life." W The Marketisation of Higher Education and Student as Consumer. Red. Mike Molesworth, Richard Scullion and Elizabeth Nixon. London-New York: Routledge: 209-225.

Neary, Mike i Gary Saunders. 2011. "Leadership and Learning Landscapes: The Struggle for the Idea of the University." Higher Education Quarterly 65(4): 332-335.

Occupy Wall Street. 2011. Post-Eviction Press Release 15 November. http://www.energybulletin.net/stories/2011-11-15/you-cant-evict-idea-whose-timehas-come-read-post-eviction-statement-ows

Solomon, Clare i Palmieri, Tania [red.]. 2011. Springtime! The New Student Rebellions. London: Verso.

Possible Futures: A Project of the U.S. Social Sciences Research Council. http://www.possiblefutures.org/.

Postone, Moishe. 1993. Time, Labor and Social Domination: A Reinterpretation of Marx's Critical Theory. New York-Cambridge: Cambridge University Press.

Postone, Moishe. 2000. Anti-Semitism and National Socialism. London: Chronos Publications.

Rancière, Jacques. 2010. Dissensus: On Politics and Aesthetics. London: Verso.

Read, Jason. 2011. "The Production of Subjectivity: from Transindividuality to the Commons." New Formations 70: 113-131.

Really Open University. 2010. “What do We Mean by »Strike, Occupy, Transform«?” Really Open University 24 February. http:/ / reallyopenuniversity.wordpress.com/ 2010/02/24/what-do-we-mean-by-strike-occupy-transform/.

Reynolds, Glenn. 2012. “A Syllabus for the »Occupy« Movement.” W all Street Journal February 17. http://online.wsj.com/article/

SB10001424052970204883304577223020110788672. html?mod=googlenews_wsj.

Richardson, Hannah. 2012 “Occupy Protest Movement to Go Into Schools.” BBC News 20 January. http://www.bbc.co.uk/news/education-16650613.

Roggoro, Gigi. 2011. The Production of Living Knowledge: The Crisis of the University and the Transformation of Labour in Europe and North America. Philadelphia: Temple University Press.

Sandlin, Jennifer, Michael O’Malley i Jake Burdick. 2011. "Mapping the Complexity of Public Pedagogy Scholarship: 1894-2010." Review of Educational Research 81(3): 338-375.

Shukaitis, Stevphen, David Graeber i Erika Biddle [red.]. 2007. Constituent Imagination: Militant Investigations, Collective Theorizations. Oakland: AK Press.

Shulman, George. 2011. "Interpreting Occupy." Possible Futures: A Project of the U.S. Social Sciences Research Council. http://www.possible-futures.org/2011/12/20/interpretingoccupy/

Smith, K. Mark. 2000. “Curriculum Theory and Practice.” http://www.infed.org/biblio/bcurric.htm. 
Smith, Matthew Noah. 2012. "Living Politically." Possible Futures: A Project of the U.S. Social Sciences Research Council. http:/ /www.possible-futures.org/2012/01/23/livingpolitically/.

Sitrin, Marina. 2012. "Horizontalism and Territory." Possible Futures: A Project of the U.S. Social Sciences Research Council. http:/ /www.possiblefutures.org/2012/01/09/ horizontalismand-territory/.

Uleman, Jennifer. 2012. “Occupy Philosophy!” Possible Futures: A Project of the U.S. Social Sciences Research Council. http:/ /www.possible-futures.org/2012/01/25/occupyphilosophy/.

University of Utopia. Anti-Curricula. http://www.universityofutopia.org/sharin.

Wacquant, Loïc. 2007. "Towards a Social Praxeology: The Structure and Logic of Bourdieu's Sociology." W An Invitation To Reflexive Sociology. Red. Loïc Wacquant i Pierre Bourdieu. Cambridge-Massachusetts: Polity: 1-60.

Žižek, Slavoj, Haseeb Ahmed i Chris Cutrone. 2012. „The Occupy Movement, a Renascent Left, and Marxism Today: An Interview with Slavoj Zizek." The Platypus Review 42 December-January: 1-6. 
Sarah Amsler - starsza wykładowczyni na Uniwersytecie w Lincoln. Jej badania skupiają się na polityce kultury, wiedzy i edukacji, roli krytycznej pedagogiki w podmiotowych i społecznych transformacjach, relacji pomiędzy praktyką kulturową i mobilizacja polityczna, roli filozofii krytycznej w życiu codziennym, polityce nadziei. Jest autorką książki The Politics of Knowledge in Central Asia: Science Between Marx and Market (2007) a także szeregu artykułów poświęconych socjologii i polityce edukacji, kultury oraz krytycznej pedagogiki. Obecnie pracuje nad projektem The Politics of Transformative Culture in Popular Art and Education i książka Educating Hope: The Pedagogies of Possibility.

\section{DANE ADRESOWE:}

Centre for Educational Research and Development

University of Lincoln

Lincoln LN6 7TS

EMAIL: samsler@lincoln.ac.uk

Mike Neary - profesor i Dziekan do spraw Dydaktyki na Uniwersytecie w Lincoln. Przed zajęciem tego stanowiska wykładał socjologię polityczną na Uniwersytecie w Warwick w latach 1994-2007. Zanim rozpoczął karierę akademicka, zajmował się młodzieżą i rozwojem lokalnej społeczności w południowym Londynie w latach 1980-1994.

\section{DANE ADRESOWE:}

University of Lincoln

Lincoln, LN7 6TS

EMAIL: mneary@lincoln.ac.uk

CYTOWANIE: Neary, Mike i Sarah Amsler. 2015. Occupy: nowa pedagogika przestrzeni i czasu? Praktyka Teoretyczna 4(18): 145-170.

DOI: $10.14746 /$ prt.2015.4.6

\section{AUTHOR: Sarah Amsler and Mike Neary}

TITLE: Occupy: New Pedagogy of Space and Time?

ABSTRACT: This paper forms the first part of a project of inquiry to understand the theoretical and practical potentials of Occupy through the recent wave of occupations that have emerged in response to the politics of austerity and precarity around the world. We do this as educators who are seeking to 'occupy' spaces of higher education inside and outside of the institutions in which we work. Occupy points to the centrality of space and time as practical concepts through which it is possible to reconfigure revolutionary activity. By dealing with the 
concept (Occupy) at this fundamental level of space and time through a critical engagement with Henri Lefebvre's notion of 'a new pedagogy of space and time', we hope to open spaces for further revolutionary transformation by extending a critique of the politics of space and time into the institutions and idea of education itself. Lefebvre considers the 'pedagogy of space and time' as a basis for a new form of 'counter-space'. He suggests that 'deviant or diverted spaces, though initially subordinate, show distinct evidence of a true productive capacity' (2008: 383), and in doing so reveal the breaking points of everyday life and the ways in which it might be appropriated as exuberant spaces full of enjoyment and hope. In the Production of Space, he identifies the space of leisure as a site within which such a resistance might be contemplated and activated. In our work we replace the principle of leisure with the concept of Occupy. We consider here how attempts to occupy the university curriculum, not as a programme of education but as the production of critical knowledge, may also constitute 'a new pedagogy of space and time'. We will describe this occupation of higher education with reference to two projects with which we are involved Student as Producer and the Social Science Centre, the former at the University of Lincoln, and the latter across the city of Lincoln.

KEYWORDS: Occupy, critical pedagogy, student as producer, Lefebvre 